Original Research Paper

\title{
Ecological valuation of city parks (Case study for Mataram City)
}

\author{
Suripto ${ }^{*}$, Jupri, A., Farista, B. ${ }^{1}$, Virgota, A. ${ }^{1}$ \& H. Ahyadi ${ }^{1}$ \\ ${ }^{1}$ Environmental Science Study Program, Faculty of Mathematics and Natural Sciences, University of Mataram, \\ Indonesia
}

\author{
Article History \\ Received : September $15^{\text {th }}, 2021$ \\ Revised : September 30 ${ }^{\text {th }}, 2021$ \\ Accepted : October 10 $0^{\text {th }}, 2021$ \\ Published : October 19 ${ }^{\text {th }}, 2021$ \\ *Corresponding Author: \\ Suripto, \\ Environmental Sciences Study \\ Program Faculty of Mathematics \\ and Natural Sciences, University \\ of Mataram, Indonesia; \\ Email: suriptobio@unram.ac.id
}

\begin{abstract}
City parks, apart from having an aesthetic function as a place for recreation, also have an ecological function with vegetation components to soften the microclimate. Vegetation analysis was carried out in six city parks in Mataram City to determine the vegetation structure. Microclimate factors of the park, namely light intensity, air temperature and humidity inside and outside the park during the day and observations of sound attenuation at night have been carried out. Climatic data is carried out to determine the park's ability to reduce heat and air temperature, increase air humidity and reduce noise and determine the park's environmental discomfort index. Of the six urban parks observed in the city of Mataram, namely the parks of Ampenan, Malomba, Udayana, Sangkareang, Mayura, and Selagalas, it is known that there are three groups of vegetation structures, namely trees-shrubs, shrubstrees, and shrubs. Vegetation with various compositions of life forms in each city park only controls 40 to $60 \%$ of the land area of the park. Urban parks in Mataram City have a low level of ability to soften the microclimate, which is below 5\%. In reducing heat and air temperature, and increasing air humidity. City parks are also known to have a low ability to reduce noise. The city parks of Ampenan, Udayana and Sangkareang have an environmental comfort level equivalent to the discomfort felt by more than $50 \%$ of the population, while the Malomba, Mayura, and Selagalas parks have a level of comfort equivalent to the discomfort felt by less than $50 \%$ of the population. The existence of urban park vegetation is only able to reduce the discomfort index of 7 to $9 \%$.
\end{abstract}

Keywords: Discomfort index, Mataram City, microclimate softening, noise reduction, vegetation of parks.

\section{Introduction}

The increase in urban population density often results in a decrease in the area of green open land, both existing and potential. This is because urban population growth is often followed by economic development, settlements, education, and culture, which encourages the conversion of nonbuilt land, including green open land into land cover in the form of buildings, roads, and other forms of physical cover that do not have vegetation.

This decrease in the area of non-built land, especially green open space, can cause changes in the microclimate in the city. Changes in the microclimate include an increase in air temperature and heat as a result of an increase in the intensity of sunlight during the day. Changes in the microclimate often give an unpleasant impression in the form of an increase in the environmental discomfort index.

High population growth along with increasing economic activity in urban areas also raises the need for motorized vehicles. The increase in the density of motorized vehicles, in addition to increasing the occurrence of air pollution, can also cause a decrease in environmental conductivity in the form of noise and an increase in the discomfort index.

One of the compensations for the implementation of the conversion of green open land is the remaining non-built land with certain conditions, position, area and distribution to be maintained as open land by growing vegetation as a cover component, and this is what we know as city parks. Thus, it can be stated that the city park is part of the remaining green open land in the city. In other 
words, city parks are part of the green open land in the city, ideally to compensate for the general reduction of open land in the city. The form of compensation is certainly related to the ability of city parks ecologically, namely to prevent or reduce the impact of decreasing open land area in the form of changes in microclimate, increased noise, and increased environmental discomfort index.

The City of Mataram as one of the cities in the eastern part of Indonesia has been and is undergoing very rapid development, both in terms of population growth, as reported by the Central Statistics Agency for The City of Mataram (2020) and in the physical infrastructure development aspect, as outlined in Mataram city spatial plan document for 2011-2031 by The Directorate General of Human Settlements, Ministry of Public Works (2020), which has an impact in the form of reducing green open space in the city.

Fitrasari et al. (2018) also reported that the increase in physical development in the city of Mataram caused the need for space to increase, so that the existence of public open space was increasingly threatened. According to the Central Statistics Agency of Mataram City (BPS Mataram, 2017), Mataram City experienced a significant increase in built space from 2008 to 2016 which reached $4.9 \%$. This is in accordance with the conclusions of the results of research conducted by Putra (2016), namely that in the implementation of development there are always challenges of environmental quality degradation.

The development carried out often occurs by means of massive exploitation of the environment to meet needs. The development carried out often uses physical and economic indicators as evidence of success. Thus, in the future, development policies are needed that are able to encourage the improvement of environmental quality to support sustainable development. Therefore, in improving the quality of the urban environment, it is necessary to develop green open spaces.

Compensation for the conversion of open land in the form of urban park development as well as the development of existing city parks has occurred in the city of Mataram (Sosman, 2014). These impacts are changes in the microclimate that reduce environmental quality, such as an increase in thermal pollution or an increase in air temperature, and an increase in the environmental discomfort index. The role of urban parks in mitigating microclimate changes is mainly determined by the structure of the vegetation in the park.

\section{Materials and Methods}

\section{Determination of sample areas}

The city parks selected as the sample area of this study are city parks that have the status of a Public Open Space according to the Mataram City Spatial Plan and are located in a central area of public activity with indicators traversed by traffic lanes with a heavy category.

\section{Analysis vegetation of parks}

Vegetation analysis of urban parks was carried out using the two-way transect method perpendicular to each other for herbaceous and shrub vegetation and using the quadratic method for shrub and tree vegetation. The length and direction of the transect is determined according to the shape and size of the park footprint. Similarly, the size, number and distribution of squares were determined according to the shape and size of the observed garden footprint (Figure 1).

Each individual herbaceous and shrub vegetation in the park affected by the transect line was observed, while for shrubs and tree vegetation, observations were made on the individuals contained in the square. Vegetation variables that were observed or measured were density and density.

\section{Density}

For herbaceous and shrub vegetation, density was observed by counting the total number of individuals of each vegetation type affected by the transect line on each transect, while for shrubs and tree vegetation, density was observed by counting the total number of individuals of each species contained in each square. 


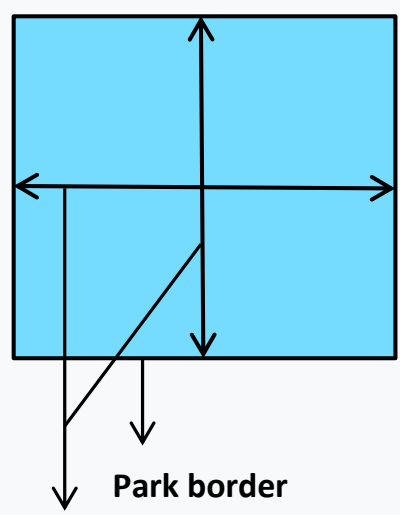

Transect line

Figure 1. Park vegetation analysis map using a combination of the two-way line design transect-square method

\section{Denseness}

For herbaceous and shrub vegetation, denseness was observed by measuring the percentage of length of coverage by all individuals of each species affected by the transect line in each transect, while for shrubs and tree vegetation, denseness was observed by measuring the percentage of total area covered by the canopy of all individuals of each species contained in every square.

\section{Measurement of microclimate variables}

Measurements of microclimate variables were carried out in the middle of a sunny day inside the park and outside the park according to a two-way perpendicular design. The climate variables measured were the intensity of sunlight, air temperature, and humidity at an altitude of $150 \mathrm{~cm}$ from the garden floor. The intensity of sunlight was measured using a lux meter with a standard plate reflection method, temperature and humidity were measured using a thermo-hygrometer application of the Weather Station.

Measurement of climatic factors is carried out at the points of the two corners of the line that are perpendicular to each other. On each line, the measurement starts from the farthest point outside the park towards the boundary of the park footprint to the center point of the park (Figure 2).

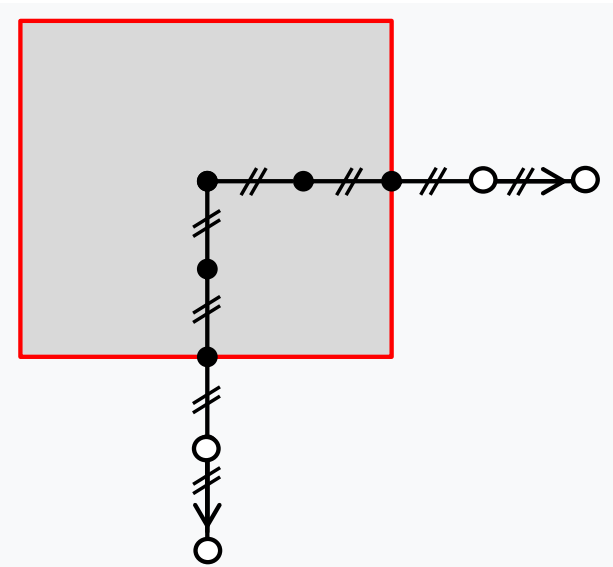

\section{- Lookout points inside the park \\ O Lookout points outside the park}

Figure 2. Map of observations of climate variables inside and outside the park site.

The length and direction of the line and the distance between the observation points are determined according to the shape and site of the park being observed. However, the number of points on each corner line in all sample areas of city parks is the same, namely 5 points ( 2 points outside the park, 1 point right at the intersection of the corner line with the edge of the park footprint, and 2 points inside the park)

\section{Sound attenuation measurement}

In addition to measuring climate variables, sound attenuation measurements were also carried out in each sample area of city parks. Measurement of sound intensity from an artificial sound source with a noise standard frequency for open space (55 db) was carried out at predetermined points according to the design of regular line intervals in the two cardinal directions. The position of the sound source at the measurement point is at a height of 150 $\mathrm{cm}$ from the ground.

Measurement of sound intensity was carried out using a sound level meter at a height of $150 \mathrm{~cm}$ from the garden floor, starting at the point of the sound source followed by points along the line at intervals to the center of the park, away from the center of the park and continued away from the garden site to the end point outside garden (Figure $3)$. 


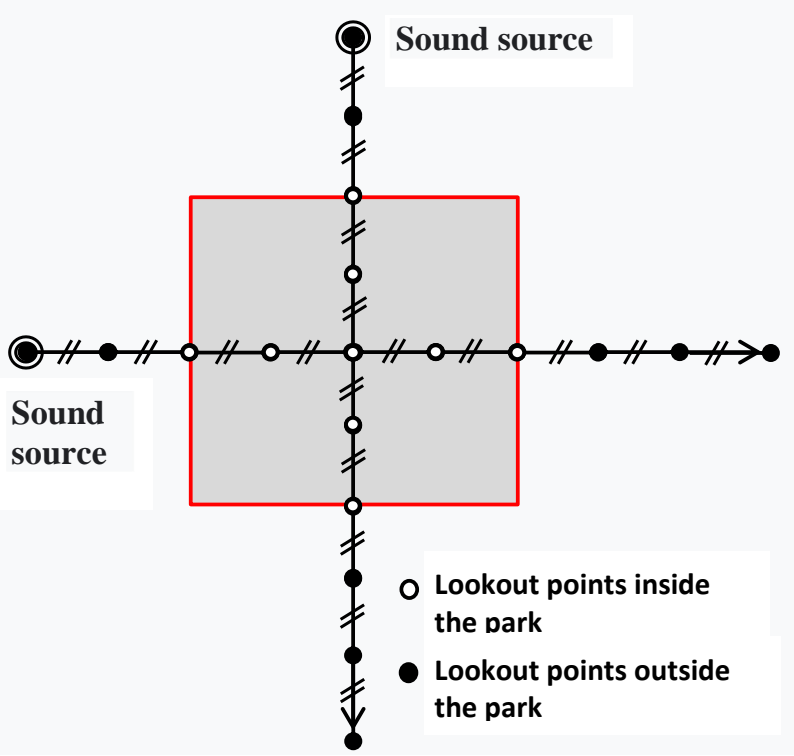

Figure 3. Map of the measurement of noise reduction in urban parks

Measurement of sound intensity is carried out in two corners of the line. The length and direction of the line and the distance between the observation points are determined according to the shape and size of the park footprint. However, the number of these sound measurement points on each corner line in all sample areas of city parks is the same, namely 10 points ( 2 points on the line outside the park from the sound source to the park, 6 points on the line inside the park, and 3 points on the line outside the park). the outside line away from the park. The combination of two-way line directions in this noise measurement is the same as in the measurement of climate variables.

\section{Data analysis}

\section{Classification of city parks based on vegetation structure}

Data on the density (D) and cover (C) of each living form of vegetation (herbs, bushes, shrubs and trees) in each sample area (city park) were used to determine the important value (IV) of each vegetation form. by using the formula:

$$
\begin{aligned}
& \mathbf{I V}_{\mathbf{i}}=\mathbf{r} \mathbf{D}_{\mathbf{i}}+\mathbf{r} \mathbf{C}_{\mathbf{i}} \\
& \mathrm{rD}_{\mathrm{i}}=\mathrm{Di} / \text { total } \mathrm{D} \text { of all vegetation forms }
\end{aligned}
$$

$$
\begin{aligned}
\mathrm{rC}_{\mathrm{i}} & =\mathrm{Ci} / \text { total } \mathrm{C} \text { of all vegetation forms } \\
\mathrm{ISi} & =\text { Important score of } \mathrm{i} \text { vegetation } \\
\mathrm{D}_{\mathrm{i}} & =\text { Density average of } \mathrm{i} \text { vegetation } \\
\mathrm{C}_{\mathrm{i}} & =\text { Cover average of } \mathrm{i} \text { vegetation } \\
\mathrm{rD}_{\mathrm{i}} & =\text { Relative density of } \mathrm{I} \text { vegetation } \\
\mathrm{rC}_{\mathrm{i}} & =\text { Relative cover of } \mathrm{i} \text { vegetation }
\end{aligned}
$$

The important value of each vegetation form (IVi) determines the dominance of the vegetation form in a sample area (city park) and the composition of form vegetation based on this importance value (IVi) is expressed as a vegetation structure. Furthermore, IVi data from all sample areas of the park were processed using the ordination technique according to Roemantyo (2011) to produce a grouping of park vegetation structures.

\section{Assessing microclimate softening ability}

Data on the intensity of sunlight, air temperature and air humidity from observation points at each corner of the line are calculated the difference at each interval in the direction from the farthest point outside the park to the point at the center of the park site. The data for the difference in microclimate variables is processed to produce the percent decrease (for light intensity and air temperature) or increase (for air humidity). The average percentage decrease or increase over the entire interval is a resume for the percentage gradation (increase or decrease) of the observed climate variable. The gradation percentage $(\mathrm{G})$ of this climate variable is calculated using the following formula:

$$
\mathrm{G}=\frac{1}{n-1} \sum_{i=1}^{n-1} \frac{\left(x_{i}-x_{i+1}\right)}{x_{i}} \times 100 \%
$$

where,

$$
\begin{aligned}
\mathrm{G}= & \text { Average gradation of } \mathrm{X} \text { in } \% \\
\mathrm{n}= & \text { number of measuring points } \\
X_{\mathrm{i}}= & \text { the price of sunlight intensity or air temperature or } \\
& \text { humidity at point } \mathrm{i} .
\end{aligned}
$$

The $G$ value is used to determine the level of ecological ability to soften the microclimate (reducing light intensity or lowering air temperature or increasing air humidity) with the following criteria (Table 1): 
Tabel 1. Criteria for the ability to soften the microclimate and reduce noise

\begin{tabular}{|c|c|}
\hline$>$ Very low ability, if & $\mathrm{G}<1 \%$ \\
\hline$>$ Low ability, if & $1 \%<\mathrm{G}<5 \%$ \\
\hline$>$ Medium ability, if & $5 \%<\mathrm{G}<10 \%$ \\
\hline$>$ High ability, if & $10 \%<\mathrm{G}<20 \%$ \\
\hline$>$ Very high ability, if & $\mathrm{G}>20 \%$ \\
\hline
\end{tabular}

\section{Assessing noise-canceling ability}

Sound intensity data from observation points in each corner of the line is calculated the difference between points or intervals in the direction of the sound source point towards and through the park, then exits and continues away from the park site until the farthest point outside the park. The data on the difference in sound intensity between these points is processed to produce the percent value of the decrease in sound intensity at each interval along the observation line.

There are four groups of data on the average percent decrease in sound intensity, namely data on the line segment from the sound source point to the park (r1), data on the line segment in the park (r2), and data on the line segment away from the park (r3) and the average percent data. decrease in sound intensity over the entire point interval (r4). The average percent decrease in sound intensity in each of the above observation line segments ( $11, \mathrm{r} 2, \mathrm{r} 3$, and $\mathrm{r} 4$ ) is calculated using the same formula, which is as follows:

$$
r=\frac{1}{n-1} \sum_{i=1}^{n-1} \frac{\left(x_{i}-x_{i+1}\right)}{x_{i}} \times 100 \%
$$

where,

$\mathrm{r}=$ average dcrease in $X$ (in \%)

$\mathrm{N}=$ number of measuring points

$X_{i}=$ value of sound intensity at point $\mathrm{i}$.

The resume for the average percent decrease in sound intensity from each corner of the line in the park (R) observed is calculated by the following formula:

$$
\mathbf{R}=r_{4}-\frac{r_{1}}{r_{4}+1 / 2 r_{2}+1 / 4 r_{3}}
$$

where,

$\mathrm{R}=$ mean percent decrease in corrected sound intensity

$r_{1}=$ average percent decrease in sound intensity in segment 1 (segment from sound source to park)

$r_{2}=$ average percent decrease in sound intensity in segment 2 (segment within the park)

$r_{3}=$ average percent decrease in sound intensity in segment 3 (outside the park segment)

$r_{4}=$ average percent decrease in sound intensity over all line segments of observation

Because at each park site two corner lines are used, two R data (R1 and R2) are produced in each park site, so to determine the level of the park's ability to muffle sound, the average of R1 and R2 is used, namely R park (RT). This RT price is used to determine the level of the park's ability to reduce noise (noise), with the same criteria as the ability to soften the microclimate.

\section{Determining the environmental discomfort index (DI)}

The discomfort index (DI) was determined from the results of measurements of air temperature and humidity in each study area. DI is used to evaluate the discomfort felt or expressed by residents or the human population in an area. DI is calculated using the following formula (Georgi \& Zefiriadis, 2006):

$\mathrm{DI}=\mathrm{T}-0.55(1-0.01 \mathrm{RH})(\mathrm{T}-14,5)$

where,

$\mathrm{DI}=$ discomfort index;

$\mathrm{T}=$ temperature $\left({ }^{\circ} \mathrm{C}\right)$;

$\mathrm{RH}=$ relative humidity $(\%)$

The criteria for determining the level of discomfort are as follows (Table 2): 
Suripto, et al. (2021). Jurnal Biologi Tropis, 21 (3): 1003 - 1012

DOI: http://dx.doi.org/10.29303/jbt.v21i3.3026

Table 2. Environmental discomfort index criteria

\begin{tabular}{lr}
\hline Feelings or expressions & DI $\left({ }^{\circ} \mathrm{C}\right)$ \\
\hline No discomfort & $<21$ \\
$\begin{array}{l}\text { Discomfort is felt by }<50 \% \text { of the } \\
\text { population }\end{array}$ & $21-24$ \\
$\begin{array}{l}\text { Discomfort is felt by }>50 \% \text { of the } \\
\text { population }\end{array}$ & $24-27$ \\
$\begin{array}{l}\text { Discomfort is felt by the majority of } \\
\text { the population }\end{array}$ & $27-29$ \\
$\begin{array}{l}\text { Discomfort is felt by all } \\
\text { Medical alarm stages }\end{array}$ & $29-32$ \\
\hline
\end{tabular}

Reference source: Georgi \& Zafiriadis, 2006)

\section{Results and Discussion}

\section{Vegetation structure of city parks in The City of Mataram}

Based on the composition of the dominant vegetation life forms, namely 1 . Herbs, 2 . Shrubs, 3 . Shrubs, and 4. trees, the vegetation structure of city parks can be grouped into 12 classes, namely 1) class $1-2,2$ ) class 1-3,3) grade 1-4, 4) grade 2-3, 5) grade 2-4, 6) grade 2-1, 7) grade 3-1, 8) grade 3-2, 9) grade $3-4,10$ ) grade $4-1,11$ ) grade $4-2$, and 12) grade 4-3. Based on the vegetation analysis, the city parks observed in Mataram City are divided into three classes, namely Class 4-3, Class 3-4, and Class 2-3.

Six urban parks in The City of Mataram were observed for their vegetation structure based on the composition of the land cover area by the life form of vegetation, namely herbs, shrubs, shrubs and trees. The composition of life forms (physiognomical structure) of vegetation in urban parks observed in Mataram City varies (Figure 4).

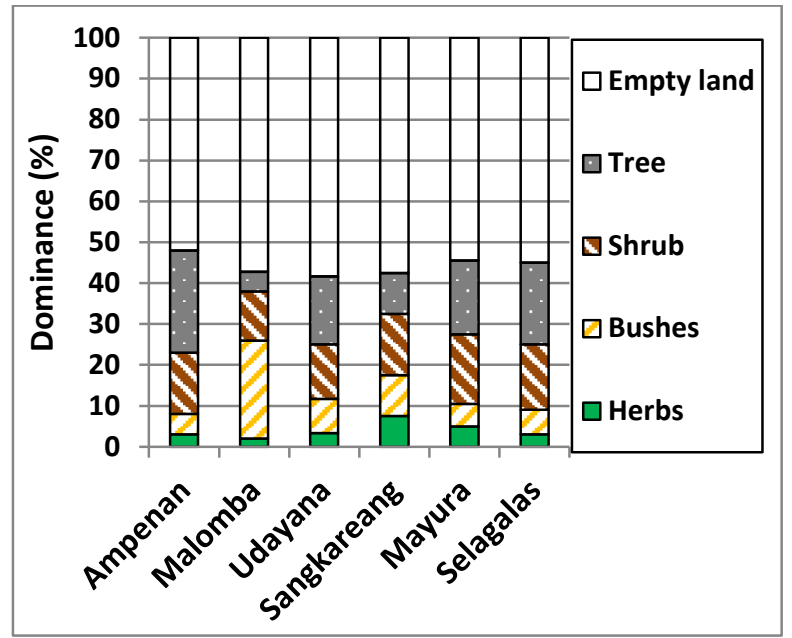

Figure 4. Vegetation structure of city parks in The City of Mataram

Old City Park of Ampenan, Udayana, and Selagalas Parks have the same class of vegetation structure, namely the vegetation is dominated by trees and shrubs (small trees or saplings). In the three parks, trees were the most dominant form of life, followed by the co-dominant shrub vegetation (Figures 4 and 5).

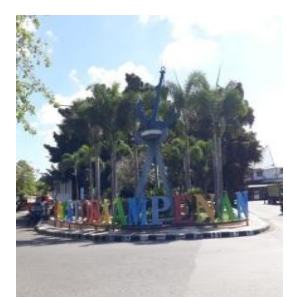

Ampenan Park

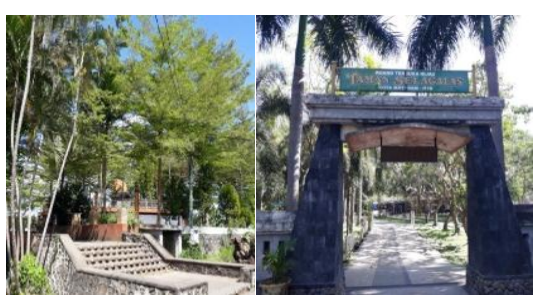

Udayana Park
Selagalas park
Figure 5. Tree-shrub vegetation structure in the city parks of Ampenan, Udaya and Selagalas

Other life forms, such as herbs and shrubs actually also grow in the city's parks, but their presence is very rare with an area covering 5 to $8 \%$ of the park area.

The vegetation structure of Sangkareang Park is the same as that of Mayura Park, namely the vegetation is dominated by shrubs and trees (Grade 3-4), while the vegetation structure of Malomba Park is the most different from the others, namely the vegetation is dominated by shrubs and shrubs (Grade 2-3) (Fig. 4 and 6). 


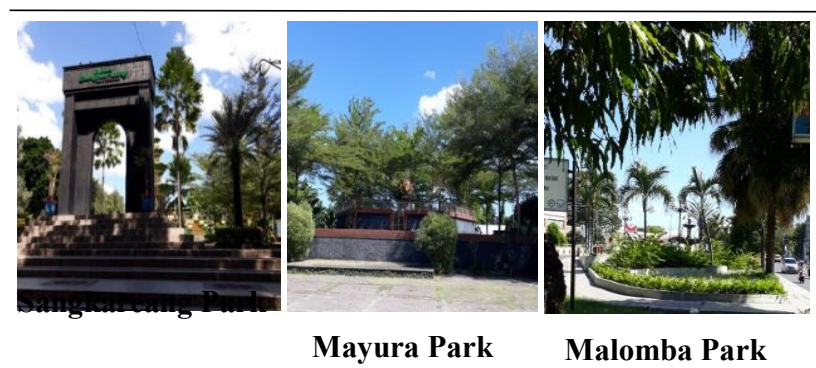

Figure 6. The tree-shrub vegetation structure in Sangkareang and Mayura Parks, and the shrub-shrub vegetation structure in The Park of Malomba.

The data also shows that in all the urban parks mentioned above, the overall vegetation only controls 40 to $45 \%$ of the total park area. Thus, 55 to $60 \%$ of the park's footprint is vacant land in the form of dirt floors and concrete or asphalt floors and buildings.

\section{The ability of the city park to soften the microclimate and reduce noise}

Vegetation structure of city parks based on the life form greatly influences its ecological ability to soften the microclimate. The softening of the microclimate in question is the percentage decrease in heat and air temperature, an increase in air humidity. A summary of the ability of city parks observed in Mataram City to reduce heat and air temperature, increase air humidity, and reduce noise can be seen in Figure 7.

The city parks observed in Mataram City, namely Ampenan Old City Park, Malomba Park, Udayana Park, Sangkareang Park, Mayura Park and Selagalas Park have varying levels of ability to reduce heat and air temperature, increase air humidity and reduce noise. The variation in the level of ecological capacity of city parks is caused by the wide variety of park footprints and the structure of the park's vegetation. However, the observed city parks are all classified as having a low ability to soften the microclimate, which is less than $4 \%$ in reducing heat and air temperature, less than $4.5 \%$ in increasing air humidity and less than 5\% in reducing sound intensity. or drown out noise.

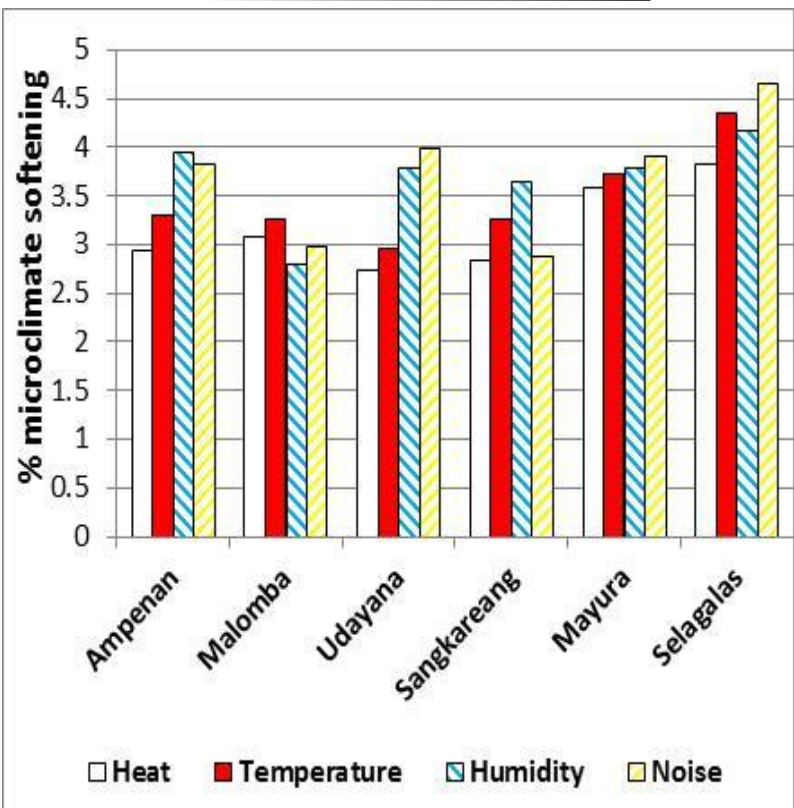

Figure 7. Summary of the ability of urban parks in Mataram City to soften the microclimate

Although the vegetation structure greatly influences the park's ability to soften the microclimate, the low ability of city parks in Mataram City to soften the microclimate mentioned above is due to the low portion of the green area (vegetated land) in the park from the total park area. . Green areas with variations in their vegetation structure only cover about 40 to $48 \%$ of the total park area. Thus, more than $50 \%$ of the park area is open land, in the form of vacant land, concrete or asphalt floors, pond water and buildings (Figures 4, 5 and 6).

The decrease in heat and air temperature and noise reduction around the park due to the presence of vegetation is caused by two factors from the presence of the vegetation, namely physical factors and physiological factors of vegetation. The magnitude of the contribution of the two vegetation factors to the reduction of heat and air temperature as well as reducing noise is determined by the structure of the vegetation itself, where the structure of the vegetation in question can affect the total surface area in contact with the air environment (Suripto \& Aksari, 2020).

Physically, plants generally have a darker color than man-made physical buildings, such as building walls, asphalt roads and so on. Darker colored surfaces absorb more and reflect less heat from the sun than lighter colored surfaces, which 
absorb less heat and reflect more of it. Thus, the presence of vegetation can physically reduce the heat and temperature of the surrounding air (Fauzan et al., 2018; Suripto et al., 2019).

Plants generally have a rougher body surface than other physical building surfaces. This rough surface of the plant body produces a greater surface area of contact with the air environment so that it can absorb more heat from the environment and reflect it less to the environment than a smooth surface (Sanger et al., 2016).

Similarly, a rough plant body surface and having a larger surface area of contact with the environment can absorb more sound intensity from the environment and reflect it less to the environment than a smooth surface and have a smaller total surface area in contact with the environment. Thus, the presence of vegetation in the city park causes the city park to have the ability to reduce noise, with variations in ability according to the structure of the vegetation contained in the park (Aluyah \& Rusdianto, 2019; Fitrasari et al., 2019).

Physiologically, plants during the day carry out photosynthesis. In the process of photosynthesis, carbon dioxide $\left(\mathrm{CO}_{2}\right)$ in the air is used. Reduction of $\mathrm{CO}_{2}$ gas in the air due to photosynthesis can reduce air heat, because $\mathrm{CO}_{2}$ gas that stores (absorbs) this air heat is reduced. On the other hand, photosynthesis produces oxygen $\left(\mathrm{O}_{2}\right)$, which gives a fresh impression to heterotroph organisms, including humans who are in the vicinity. In addition, plants are also able to use environmental heat to carry out transpiration, especially by their leaves through stomata, which produce water vapor $\left(\mathrm{H}_{2} \mathrm{O}\right)$ to the environment (Annisa et al., 2015).

Thus, the presence of vegetation can increase the humidity of the surrounding air. Vegetation with small crowns but in large numbers has a larger surface area in contact with the environment than a single canopy with the same size as the combined small crowns. Thus, the dominance of vegetation in the form of shrubs and shrubs is more important than the dominance of tree forms for the same area of coverage (Destriana et al., 2013).

\section{Environmental discomfort index}

Based on the temperature and humidity data inside the park and outside the park, it is then possible to calculate the discomfort index in the park environment. The discomfort index (DI) was measured inside the park and outside the park. The ID price difference is then calculated to produce the percentage decrease in ID, which is then used to determine the park's ability to reduce the environmental discomfort index.

The results show that in the area of Mataram City, based on daily temperature and humidity conditions, it is more often felt less comfortable or less comfortable (index of discomfort is more than 25 ), and the presence of city parks with various vegetation structures can reduce at least 7 to $9 \%$. discomfort index (Table 3 and Figure 8).

Table 3. Discomfort Index in the city parks of Mataram City

\begin{tabular}{llll}
\hline & $\begin{array}{l}\text { Inside the } \\
\text { garden }\end{array}$ & $\begin{array}{l}\text { Outside the } \\
\text { garden }\end{array}$ \\
\hline Ampenan & $24.05 \mathrm{c}$ & $26.04 \mathrm{c}$ \\
Malomba & $24.00 \mathrm{~b}$ & $25.94 \mathrm{c}$ \\
Udayana & $24.09 \mathrm{c}$ & $25.90 \mathrm{c}$ \\
Sangkareang & $24.23 \mathrm{c}$ & $26.14 \mathrm{c}$ \\
Mayura & $23.76 \mathrm{~b}$ & $25.84 \mathrm{c}$ \\
Selagalas & $23.72 \mathrm{~b}$ & $26.05 \mathrm{c}$ \\
\hline
\end{tabular}

Information:

b : Discomfort is felt by $<50 \%$ of the population

c : Discomfort is felt by $>50 \%$ of the population

The range of ecological capabilities of the city parks mentioned above is classified as moderate and some urban parks, such as the parks of Ampenan, Udayana, and Sangkareang, did not cause a decrease in the local environmental discomfort index class, which remained in a condition where discomfort was felt. by $>50 \%$ of the population.

However, the other three parks, namely the Malomba, Mayura, and Selagalas parks, although with the same level of ability as the three city parks mentioned earlier, namely the moderate level of ability but can lower the discomfort index to a lower class, namely from discomfort felt by $>50 \%$ of the population to discomfort felt by $<50 \%$ of the population. 


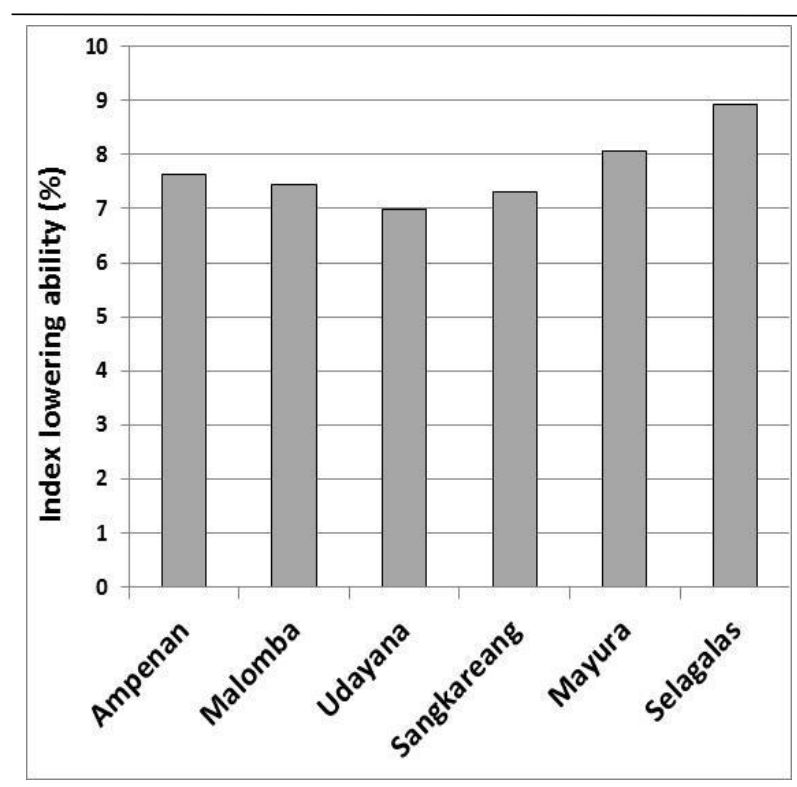

Figure 8 . The ability of city parks in Mataram City to reduce the environmental discomfort index

\section{Conclusions}

Of the six urban parks observed in Mataram City, it is known that there are three groups of vegetation structures, namely tree-shrub vegetation, shrub-tree vegetation, and shrub-dwelling vegetation. Vegetation with various compositions of life forms in each city park only controls 40 to $60 \%$ of the land area of the park. Garden vegetation in Mataram City has a low ability to soften the microclimate, which is below $5 \%$. In reducing heat and air temperature, increasing air humidity and reducing noise.

The analysis of park vegetation was carried out only based on life forms or physiognomy studies) and no taxonomic data collection or floristic studies were carried out. Actually, floristic studies are needed to complete the discussion of the ecological function of the variation of vegetation according to its position in taxonomy. Observations of microclimate factors which include air temperature and humidity cannot be carried out in the field at the same time, so that it can reduce the validity of the data, especially for calculating the environmental discomfort index. Thus, it is necessary to observe the effect of vegetation variation on the two climate variables in the experimental design.

\section{Acknowledgment}

This research was funded by the PNBP Program of The Faculty of Mathematics and Natural Sciences through the approval of Research and Community Service Institute, University of Mataram. Thanks were also conveyed to students of Environmental Science at the Study Program of Environmental Science, Faculty of Mathematics and Natural Sciences, University of Mataram in the even semester of the 2020/2021 academic year.

\section{References}

Aluyah, C., \& R. Rusdianto (2019). Pengaruh jenis dan jumlah pohon terhadap iklim mikro di Taman Purbakala Bukit Siguntang Kota Palembang Provinsi Sumatera Selatan. Sylvia. 7(2): 53-59.

Annisa, N., Kurnain, A., Indrayatie, E.R. \& S.B. Peran (2015) Iklim mikro dan indeks ketidaknyamanan taman kota di Kelurahan Komet Banjar Baru. EnviroScienteae. 11:143-151.

Destriana, N. \& Zain, A.F.M .(2013). Pengaruh Struktur Vegetasi terhadap Iklim Mikro di Berbagai Land Use Di Kota Jakarta. https://repository.ipb.ac.id/handle/123456789 $\underline{163701}$

Badan Pusat Statistik Kota Mataram. (2020). Jumlah Penduduk (Jiwa), 2018-2020 https://mataramkota.bps.go.id/indicator/12/96 /1/jumlah-penduduk.html

Direktorat Jenderal Cipta Karya Kementerian Pekerjan Umum (2020). Rencana Tata Ruang Kota Mataram 2011-2031. https://sippa.ciptakarya.pu.go.id/sippa_online /ws file/dokumen/rpi2jm/DOCRPIJM 890f9 $\underline{013 \mathrm{e} 7}$

Fauzan, E.P., Irwan, S.N.R. \& R. Rogomulyo (2018). Fungsi Vegetasi Sebagai Pengendali Iklim Mikto dan Pereduksi Suara Di Tiga Taman Kota DKI Jakarta. http://etd.repository.ugm.ac.id/home/detail_p encarian/164425 
Fitrasari M.P., Sugianthara, A.A.G. \& L.S. Yusiana (2018). Perencanaan ruang terbuka public di Desa Dasan Cermen,Kota Mataram untuk mendukung aktivitas budaya lokal. $J$. Arsitektur Lansekap. 4(1). 10-19.

Georgi, N.J. \& K. Zafiriadis (2006). The impact of park tres on microclimate in urban áreas. Urban Ecosystem. 9:195-209.

Roemantyo, S. (2011). Struktur dan komposisi vegetasi hutan semusim habitat Curik Bali (Leucopsar rithschild) di kawasan Labuan Lalang, Taman Nasional Bali Barat. Jurnal Biologi Indonesia. 7(2): 361- 374.

Sanger, Y.Y.J. Rogi, R. \& Rombang, J.A. (2016). Pengaruh tipe tutupan lahan terhadap iklim mikro di Kota Bitung. Agri-SosioEkonomi. 12 (3A):105-116.
Setyowati, D.L. (2008). Iklim mikro dan kebutuhan ruang terbuka hijau di Kota Semarang (The micro climate and need of green open space for The City of Semarang). J. Manusia dan Lingkungan. 15(3):125-140.

Sosman, A. (2014). Kajian terhadap perlindungan dan pengelolaan lingkungan hidup dalam tata ruang Kota Mataram (Studying to protect and manage environment in Mataram Town). Jurnal IUS. 2(5): 349-366.

Suripto \& S.Y. Aksari (2020). Evaluasi Ekologis Pohon Pelindung Kampus Universitas Mataram. Jurnal Pengabdian Magister Pendidikan IPA. 3 (2): 247-257

Suripto, Sukenti, K., Sukiman, Rohyani, I.M. \& A. Jupri (2019). Microspore analysis for genotoxicity of polluted atmospheric environment (The case study in The Mataram City ). J. Biologi Tropis. 19 (2):154-160. 